\title{
Development and Yield of Irrigated Sugarcane as Affected by Nitrogen Sources and Rate in Brazilian Cerrado Oxisol
}

\author{
N. F. da Silva ${ }^{1}$, F. N. Cunha $^{1}$, M. B. Teixeira ${ }^{3}$, F. A. L. Soares ${ }^{1}$, E. C. da Silva ${ }^{1}$, R. D. Coelho ${ }^{2} \&$ F. R. Cabral Filho ${ }^{1}$ \\ ${ }^{1}$ Hydraulic and Irrigation Laboratory, IF Goiano-Campus Rio Verde, Rio Verde, GO, Brazil \\ ${ }^{2}$ DER-ESALQ/USP, Piracicaba, SP, Brazil \\ Correspondence: N. F. da Silva, Hydraulic and Irrigation Laboratory, IF Goiano-Campus Rio Verde, Rio Verde, \\ GO, Brazil. E-mail: nelmiciofurtado@gmail.com
}

Received: October 15, 2018

Accepted: December 1, 2018 Online Published: February 15, 2019

doi:10.5539/jas.v11n3p267

URL: https://doi.org/10.5539/jas.v11n3p267

\begin{abstract}
Sugarcane is the most promising crop among renewable biofuels producers and one of the countries that produces the most green matter per unit area, whose greater limitations to productivity are mainly related to the adequate availability of water and mineral nutrients, in particular nitrogen $(\mathrm{N})$. Based on the hypothesis that the source and the availability of nitrogen influence the growth, development and yield of irrigated sugarcane in the cerrado region. The objective of this study was evaluate the biometric variables and yield of irrigated sugarcane, in the cane-plant cycle, as affected by source and nitrogen rate. The soil utilized was an Oxisol (Rhodic Hapludox), cerrado (savannah) phase. The experiment was carried out at Farm of the Raízen Mill, located in the municipality of Jataí, Goias State, Brazil. The variety IACSP95-5000 was used in a randomized block design, analyzed in a split-split-plot scheme, with three replicates. The treatments were four $\mathrm{N}$ rates $\left(0,60,120\right.$ and $\left.180 \mathrm{~kg} \mathrm{ha}^{-1}\right)$; two fertilizer sources (urea and ammonium nitrate). The factors evaluated were in the plots of four doses of $\mathrm{N}(0,60$, 120 and $180 \mathrm{~kg} \mathrm{ha}^{-1}$ ). In the subplot two sources of $\mathrm{N}$ (urea and ammonium nitrate) and as sub-subplot were represented by four evaluation periods (210, 250, 290 and 330 days after the planting-DAP). The irrigation was by sprinkling, in a central pivot. The evaluated variables were: plant height, stalk diameter, total number of leaf, leaf area, number of industrializable tillers, stalk yield, pointer yield and total recoverable sugars. The highest stalk yield, pointer yield and total recoverable sugars occurred at the average dose of $143.61 \mathrm{~kg} \mathrm{ha}^{-1}$ of $\mathrm{N}$, with an average increase of $25.87 \%$.
\end{abstract}

Keywords: Saccharum spp., IACSP95-5000, ammonium nitrate, urea, cerrado

\section{Introduction}

Sugarcane (Saccharum spp.) is of great importance for the Brazilian energy sector, as it is an alternative energy source that is environmentally sustainable and renewable. The efficiency of sugarcane production has evolved in recent years according to the productive environments found. These gains in efficiency are the result of improvements in management practices and technology applied to sugarcane plantations. The irrigation system has already played a fundamental role as one of the main instruments for the modernization of Brazilian agriculture, allowing enormous benefits to the cultivation of sugarcane (Dantas Neto et al., 2006; Farias et al., 2008, Dalri \& Cruz, 2008). The mechanized harvest without burning, in association with the use of agroindustrial by-products and the application of nitrogen fertilizers, have altered the dynamics of the nutrient cycling at the atmosphere-straw-to-straw interface (Resende et al., 2006; Pinheiro et al., 2010; Singh et al., 2011; Rossi et al., 2013).

Nitrogen fertilization stands out as one of the cultural practices with the greatest demand for research on sugarcane, since $\mathrm{N}$ studies present very variable and often even contradictory results (Korndörfer et al., 2002). However, there are many studies that show the importance of $\mathrm{N}$ in the sugarcane crop (Wiedenfeld and Enciso, 2008, Silva et al., 2009; Franco et al., 2011). To Cabral Filho et al. (2018) the appropriate application of agricultural inputs, contributes to the preservation of the environment, besides optimizing the enterprise's profitability, as it allows greater productivity and minimizes waste.

Sugarcane has been undergoing changes in the management practices in the field. The main change is perhaps the transition from manual harvest with the previous firing of the cane field to mechanized harvest without fire 
extinguishing. Harvest without burning ensures the permanence of the crop residues (leaves and pointers) on the soil, and changes the dynamics of mineralization-immobilization of $\mathrm{N}$ in the sugarcane systems. In addition, $\mathrm{N}$-organic mineralization has a positive effect on plant nutrition (Vitti et al., 2011; Holst et al., 2012; Trivelin et al., 2013).

Oliveira et al. (2011) found that the evaluation of some plant morphological variables such as height, diameter, leaf area and production make it possible to identify the productive capacity of the crop, as well as to analyze the effects of the cultural management adopted on the species. Thus, several factors may interfere in the productivity and technological quality of the sugarcane, which in the end represents the integration of the different conditions to which the crop was subjected (Gilbert et al., 2006). According to Machio (2011), the varietal characteristics define the number of stalks per plant, stem height and diameter, leaf length and width, and shoot architecture, the expression of these characters being strongly influenced by the climate, management and cultural practices.

In the literature, several studies show the importance of nitrogen in the sugarcane crop (Silva et al., 2009), mainly because it is a constituent part of nucleic acids and amino acids, precursors of proteins, directly or indirectly participating in several biochemical processes (Silva et al., 2006). In the present study, the effect of nitrogen fertilization on irrigated sugarcane was determined by the use of nitrogen oxides in the production of sugarcane (Oliveira et al., 2014; Silva et al., 2015; Cunha et al., 2016).

At present, the $\mathrm{N}$ rates recommended for cane-plant fall short of the actual crop requirements and, in addition, considering that microbial immobilization and soil $\mathrm{N}$ losses reduce the concentration of nutrient available to the crop, especially in the irrigated grown and system with maintenance of the straw and in soils of low or medium fertility, it is notorious that sugarcane, in the cane-plant cycle, in this condition of $\mathrm{N}$ deficiency would not be able to express all its productive potentiality. In this context, it is fundamental to evaluate the behavior of sugarcane in different production environments.

Thus, based on the hypothesis that the source and the availability of nitrogen influence the growth, development and productivity of irrigated sugar cane in the cerrado region, this study aimed to evaluate biometric characteristics and yield to define the best nitrogen source and rate of fertilization in irrigated sugarcane, in the cane-plant cycle, in a very clayey dystrophic Red Latosol, cerrado phase.

\section{Material and Methods}

The experiment was carried out under field conditions, during the 2014/2015 growing season, in an area at Rio Paraíso II Farm (Raízen plant Mill, in the municipality of Jataí, GO. The geographical coordinates of the site are $17^{\circ} 44^{\prime} 2.62^{\prime \prime} \mathrm{S}$ and $51^{\circ} 39^{\prime} 6.06^{\prime \prime} \mathrm{W}$, with an average altitude of 907 meters. According to the classification of Köppen and Geiger (1928), the climate of the place is type Aw, tropical, with rainfall from October to April, and dries from May to September. The maximum temperature ranges from 35 to $37{ }^{\circ} \mathrm{C}$, and the minimum of 12 to 15 ${ }^{\circ} \mathrm{C}$ (in the winter there are occurrences of up to 5 degrees). The annual precipitation reaches approximately 1,800 $\mathrm{mm}$, but poorly distributed throughout the year, according to the climatic data shown in Figure 1.

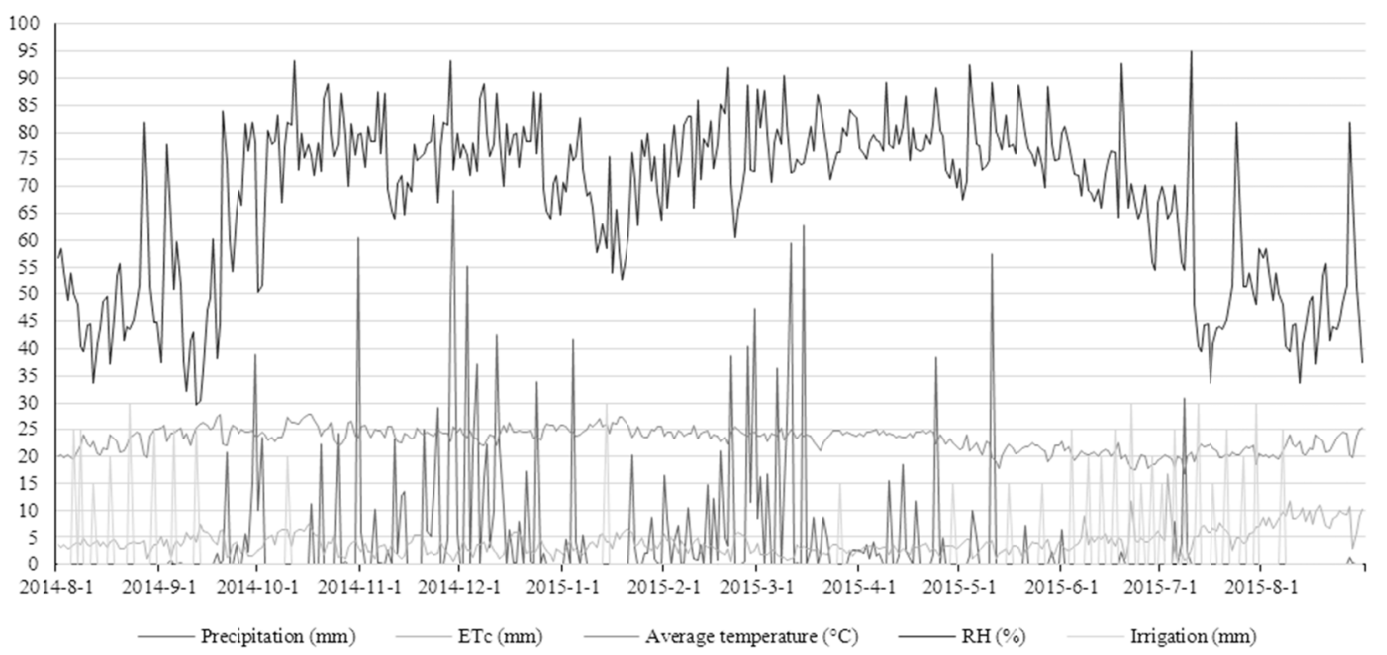

Figure 1. Daily water balance in the period resulting from the experiment, Jataí-GO, Brazil, harvest 2014/15

Source: INMET Normal Station-Jataí-GO. 
The soil of the experimental area is classified as Dystropherric Typic Rhodic Hapludox soil (Soil Taxonomy, 2010) and dystroferric Red Latosol, very loamy, cerrado (savanah) phase (Santos et al., 2013). The experimental area has a history of renovation of the sugarcane plantation of seven years of cultivation. The chemical, physical-water, granulometry and textural classification of the samples collected previous to the installation of the experiment are described in Table 1.

Table 1. Chemical, physical-water, granulometry and soil textural classification of the experimental area, $0-0.10$, 0.10-0.20 and 0.20-0.40 m depth, Jataí - GO, Brazil, 2014/15 harvest

\begin{tabular}{|c|c|c|c|c|c|c|c|c|}
\hline Layers & $\mathrm{pH}$ & O.M. & $\mathrm{P}_{\text {Resin }}$ & $\mathrm{S}$ & $\mathrm{K}$ & $\mathrm{Ca}$ & $\mathrm{Mg}$ & $\mathrm{Al}$ \\
\hline $\mathrm{m}$ & $\mathrm{CaCl}_{2}$ & $\mathrm{~g} \mathrm{dm}^{-3}$ & \multicolumn{2}{|c|}{------- $\mathrm{mg} \mathrm{dm}^{-3}$------- } & \multicolumn{4}{|c|}{---------------- $\mathrm{mmol}_{\mathrm{c}} \mathrm{dm}^{-3}$---------------- } \\
\hline $0-0.10$ & 5.9 & 72 & 45 & 13 & 9.9 & 53 & 22 & $<1$ \\
\hline $0.10-0.20$ & 5.6 & 46 & 13 & 26 & 12.1 & 31 & 12 & $<1$ \\
\hline $0.20-0.40$ & 5.2 & 41 & 8 & 91 & 8.9 & 15 & 6 & $<1$ \\
\hline Layers & $\mathrm{H}+\mathrm{Al}$ & CEC & $\mathrm{V}$ & $\mathrm{B}$ & $\mathrm{Cu}$ & $\mathrm{Fe}$ & $\mathrm{Mn}$ & $\mathrm{Zn}$ \\
\hline $\mathrm{m}$ & \multicolumn{2}{|c|}{------ $\mathrm{mmol}_{\mathrm{c}} \mathrm{dm}^{-3}$----- } & $\%$ & \multicolumn{5}{|c|}{ 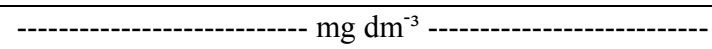 } \\
\hline $0-0.10$ & 22 & 106.9 & 79 & 0.28 & 1.2 & 39 & 3.4 & 2.1 \\
\hline $0.10-0.20$ & 28 & 83.1 & 66 & 0.17 & 1.6 & 36 & 1.6 & 1.0 \\
\hline $0.20-0.40$ & 21 & 60.9 & 49 & 0.12 & 1.4 & 25 & 0.7 & 0.3 \\
\hline \multirow{2}{*}{ Layers } & \multicolumn{3}{|c|}{ Granulometry } & \multirow{2}{*}{\multicolumn{3}{|c|}{ Textural classification }} & \multirow{2}{*}{$\theta_{\mathrm{CC}}$} & \multirow{2}{*}{$\theta_{\mathrm{PMP}}$} \\
\hline & Sand & Silt & Clay & & & & & \\
\hline $\mathrm{m}$ & \multicolumn{6}{|c|}{ 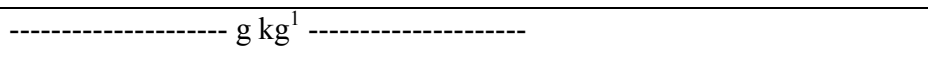 } & \multicolumn{2}{|c|}{---- $\mathrm{cm}^{3} \mathrm{~cm}^{-3}---$} \\
\hline $0-0.10$ & 96 & 82 & 822 & \multicolumn{3}{|c|}{ Clayey } & \multirow{2}{*}{46.3} & \multirow{2}{*}{22.6} \\
\hline $0.10-0.20$ & 97 & 82 & 822 & Claye & & & & \\
\hline $0.20-0.40$ & 85 & 71 & 845 & Claye & & & 45.8 & 22.6 \\
\hline
\end{tabular}

Note. Manual of chemical analysis for fertility evaluation of tropical soils (Raij et al., 2001). O.M.: Organic matter; CEC: Cation exchange capacity; V: Bases saturation; $\theta_{\mathrm{FC}}$ : Water content in field capacity; $\theta_{\mathrm{PWP}}$ : Water content at the permanent wilting point.

The experimental design was a randomized block design, analyzed in a split-split-plot scheme, with three replicates. The treatments were four $\mathrm{N}$ rates $\left(0,60,120\right.$ and $\left.180 \mathrm{~kg} \mathrm{ha}^{-1}\right)$; two fertilizer sources (urea and ammonium nitrate). The factors evaluated were in the plots of four doses of $\mathrm{N}\left(0,60,120\right.$ and $\left.180 \mathrm{~kg}^{-1}\right)$. In the subplot two sources of $\mathrm{N}$ (urea and ammonium nitrate) and as sub-subplot were represented by four evaluation periods $(210,250,290$ and 330 days after the planting-DAP).

Nitrogen fertilization was performed according to the treatments, at 60 days after planting, applied to the haul, on the line side $(0.20 \mathrm{~m})$, contrary to the slope of the land. All treatments were fertilized at planting with phosphorus (100 kg ha ${ }^{-1}$ of $\mathrm{P}_{2} \mathrm{O}_{5}$ ) as triple superphosphate, potassium $\left(80 \mathrm{~kg} \mathrm{ha}^{-1}\right.$ of $\mathrm{K}_{2} \mathrm{O}$ ) as potassium chloride, and micronutrients, according to the results from soil analysis and recommendation of Sousa and Lobato (2004).

Soil preparation was performed by the conventional system, by means of plowing and harvesting, followed by opening of the machining planting grooves, according to the experience of the plant the number of buds per meter, according to the recommendations for the respective variety. The variety used was the IACSP95-5000.

The herbicides, insecticides, fungicides and other products for control of invasive plants, pests and diseases were used whenever necessary.

The irrigation was carried out by a central pivot ZIMMATIC, monitoring the irrigation following the farmer recommendation. During the crop cycle, meteorological data of maximum and minimum temperature $\left({ }^{\circ} \mathrm{C}\right)$, maximum and minimum relative humidity $(\%)$, wind speed $\left(\mathrm{m} \mathrm{s}^{-1}\right)$, solar radiation $\left(\mathrm{kJ}^{2}\right)$ and rainfall precipitation were collected daily $(\mathrm{mm})$, through a meteorological station. The water balance and the soil water balance were generated with the aid of irrigation management software (IRRIGER ${ }^{\circledR}$ ). In the software, climate monitoring is used to estimate the daily water consumption of sugarcane, for the irrigation blade to be applied, at the appropriate moment to irrigate. The software uses the Penman-Monteith method (FAO Standard, 1991), adapted by Allen et al. (1989) for the estimation of evapotranspiration on a daily scale, with micrometeorological data of solar radiation, air temperature, wind speed and relative humidity. 
Two tillers were collected in the central lines of the subplots to evaluate the variables plant height (PH), stalk diameter (SD), internodes number (IN), internodes length (IL), green leaf number (GLN), diad leaf number (DLN), total leaf number (TLN) and leaf area (LA), according to Benincasa (2003), the height of the plant was measured using a tape measure, from the soil to the collar of the leaf +1 (sheet +1 is the one that can be completely visualized the collar), and expressed in $\mathrm{m}$; The stalk diameter was determined with the aid of a pachymeter at the base of the plant, and expressed in $\mathrm{mm}$; The internodes length was obtained by counting in the whole stalk of the plants from the detachment of the first stalks; The length of the trapezoid was determined by means of a ruler graduated at $0,30 \mathrm{~m}$ across the top of the plants from the first stalk detachment and expressed in $\mathrm{m}$; The leaf number was determined by counting the leaf fully expanded, being considered as green leaf at least $20 \%$ of green area, counted from leaf +1 ; The leaf area was determined by counting the number of green leaf (fully expanded leaf with a minimum of $20 \%$ of green area counted from leaf +1 ) and by measuring leaf +3 , the length and width of the leaf in the median portion, according to methodology described by Hermann and Câmara (1999):

$$
\mathrm{AF}=\mathrm{C} \times \mathrm{L} \times 0.75 \times(\mathrm{N}+2)
$$

where,

C: sheet length +3 ; L: sheet width +3 ; 0.75 : correction factor for leaf area of the crop; $\mathrm{N}$ : number of open leaf with at least $20 \%$ green area.

The sugarcane ${ }^{\circ}$ Brix was monitored in the field during the last four weeks prior to harvest. For the rational determination of the sugarcane harvest point, the parameter known as the Maturation Index (MI) determined in the field was used, using a portable refractometer. The IM values are: (a) less than 0.60 for green cane; (b) between 0.60 and 0.85 for cane in the process of maturation; (c) between 0.85 and 1 for mature cane; and (d) greater than 1 for cane in the process of sucrose decline (Rossetto, 2012).

Harvesting was performed on 08/25/2015, stalk yield (SY) and pointer yield (PY) was determined by total weighing of stalks and pointers present in the respective subplots, quantifying the weight of stalks and pointers present in $2 \mathrm{~m}$ of the two central lines, whose value was extrapolated to $\mathrm{tha}^{-1}$. For this, the cut was made as close as possible to the soil. The stalks were then untidy and had the pointer highlighted. They were then weighed in a hook-type digital scale, with a Soil Control mark (accuracy $=0.02 \mathrm{~kg}$ ), with a capacity of $50 \mathrm{~kg}$. The number of industrializable tillers averaged per linear meter was determined by counting the number of plants in $2 \mathrm{~m}$ of the two plot lines.

Samples of 10 stalks per treatment were collected for the determination of the total sugar recoverable values (TSR), according to the Consecana system (2006), in the Agri-industrial Laboratory of the Raízen Plant, in Jataí-GO.

The data obtained were analyzed statistically by variance analysis and when detected significant effects (F test $5 \%$ of probability), they were adjusted to regression equations. Linear and quadratic components were tested and chosen the model with larger significant degree. The means for $\mathrm{N}$ source (urea and ammonium nitrate) were compared by the Tukey test to $5 \%$ of probability. The statistical analyses were carried out using the SAS package 8.02 (SAS, 2001).

\section{Results}

In the analysis of variance, it was observed that the variable height plant (HP) have significant influence for the time factor, the stalk diameter variable (SD) was significant for the $\mathrm{N}$ rate factor and for the time factor alone, the variable internodes length (IL) was significant for the source and time factor alone and the variable internodes number (IN) was significant for the time factor, evidencing that the evaluation period had an effect during all phases of growth and development of sugarcane plant, and this response was dependent on the $\mathrm{N}$ rate factor for SD, and the $\mathrm{N}$ source factor for IL.

For the HP as affected by the DAP, it was observed that there was an estimated linear maximum increase of $2.31 \mathrm{~m}$ at $330 \mathrm{DAP}$, corresponding to $0.60 \mathrm{~m}(25.97 \%)$ in relation to the $210 \mathrm{DAP}$ (Figure 2A). Regarding SD as affected by DAP, it was observed that there was an estimated maximum linear increase of $33.90 \mathrm{~mm}$ at $330 \mathrm{DAP}$, which corresponds to $3.02 \mathrm{~mm}(8.91 \%)$ in relation to $210 \mathrm{DAP}$ (Figure 2B). For the IL as affected by the DAP, it is observed that there was the minimum linear reduction estimated from $0.0967 \mathrm{~m}$ to $330 \mathrm{DAP}$, which corresponds to $0.024 \mathrm{~m}(19.88 \%)$ in relation to the $210 \mathrm{DAP}$ (Figure 2C).

Regarding IN as affected by the DAP, it was observed that there was an estimated maximum linear increase of 20.76 internodes at 330 DAP, which corresponds to 6.90 internodes (33.24\%) in relation to $210 \mathrm{DAP}$ (Figure 2D). 

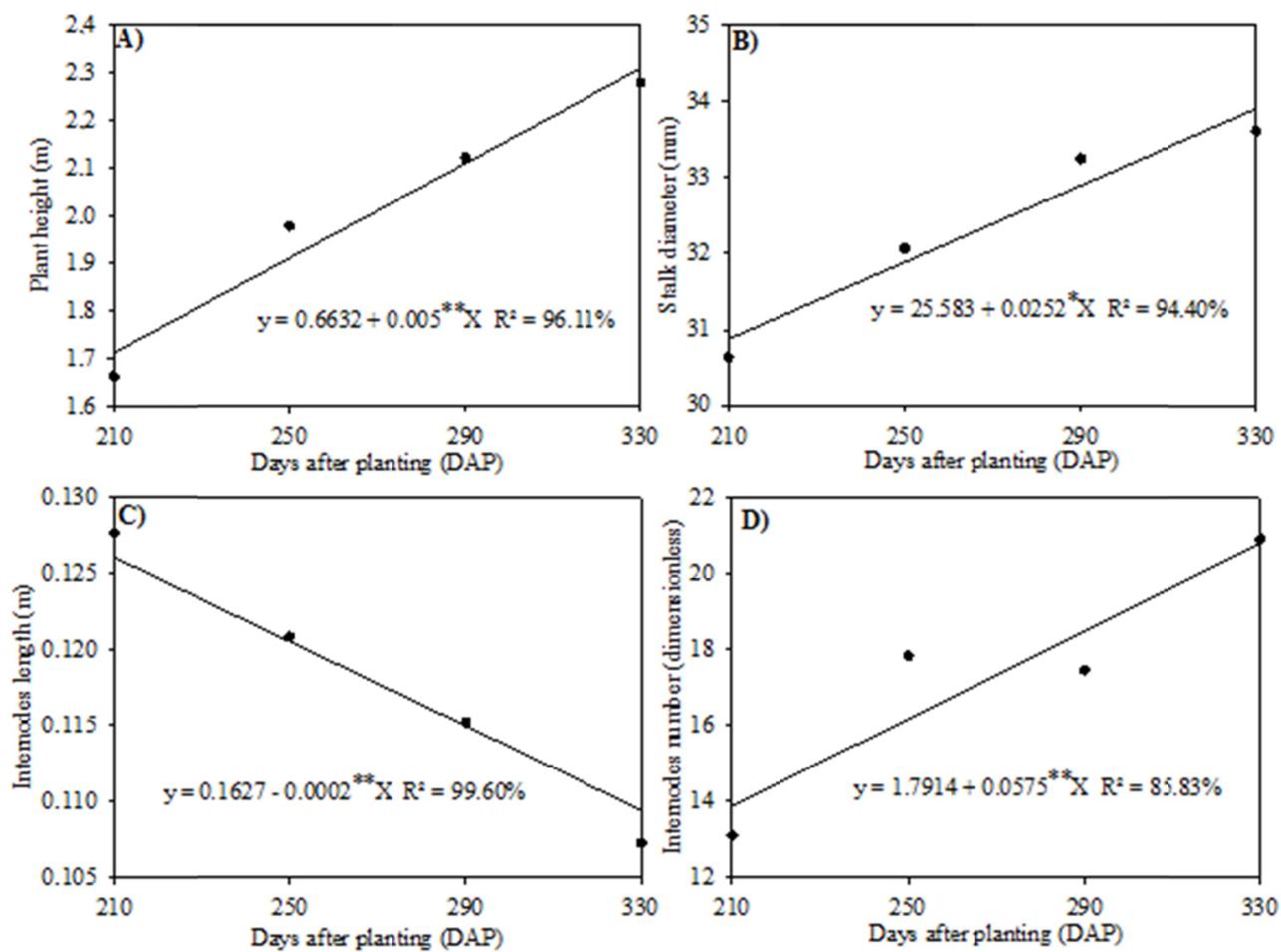

Figure 2. Averages of plant height (A), stalk diameter (B), internodes number (C), internodes length (D) in function of the season of evaluation, Jataí-GO, Brazil, crop 2014/15

Note. ${ }^{* *}$ and $*$ significant respectively at $1 \%$ and $5 \%$ of probability according to test $\mathrm{F}$.

In the average test for the IL variable as a function of the $\mathrm{N}$ source, it is observed that the ammonium nitrate source obtained the highest mean in relation to urea, with a percentage difference of $1.77 \%$ (Table 2).

Table 2. Mean test for the variable internodes number (IN), in function of the source of nitrogen, Jataí-GO, Brazil, crop 2014/15

\begin{tabular}{ll}
\hline \multirow{2}{*}{ Source of nitrogen } & Internodes number $(\mathrm{IN})$ \\
\cline { 2 - 2 } & Mean $(\mathrm{m})$ \\
\hline Urea & $0.1167 \mathrm{~b}$ \\
Ammonium nitrate & $0.1188 \mathrm{a}$
\end{tabular}

Note. Means followed by the same letter in the columns do not differ according to Tukey test at $5 \%$ probability.

In the unfolding of the $\mathrm{N}$ rate factor within each season for NFT, it was observed that there was an estimated linear increase of 3.20 and 4.88 leaves with $180 \mathrm{~kg} \mathrm{~N} \mathrm{ha}^{-1}$, corresponding to 18.66 and $19.98 \%$, respectively, for 210 and 250 DAP. At 290 and 330 DAP, it was observed that there was an estimated maximum quadratic increase of 27.96 and 32.46 leaves, respectively, with 156.66 and $173.33 \mathrm{~kg} \mathrm{~N} \mathrm{ha}^{-1}$, corresponding to the increase of 7.36 leaves (26.32\%) and 9.01 leaves (27.76\%) (Figure 3B).

In the unfolding of the time factor within each $\mathrm{N}$ rate for the TLN, it was observed that there was an estimated linear increase of 9.48, 12.3, 15.50 and 15.07 leaves at 330 DAP, corresponding to $39.34,43,30,47.43$ and $45.83 \%$, respectively, for $0,60,120$ and $180 \mathrm{~kg} \mathrm{~N} \mathrm{ha}^{-1}$ (Figure 3C). In the unfolding of the source factor within each season for TLN, it is observed that there was an estimated linear increase of 11.11 and 15.07 leaves at 330 DAP, corresponding to 39.78 and $48.46 \%$, respectively, for ammonium nitrate and urea (Figure 3D). 
A)
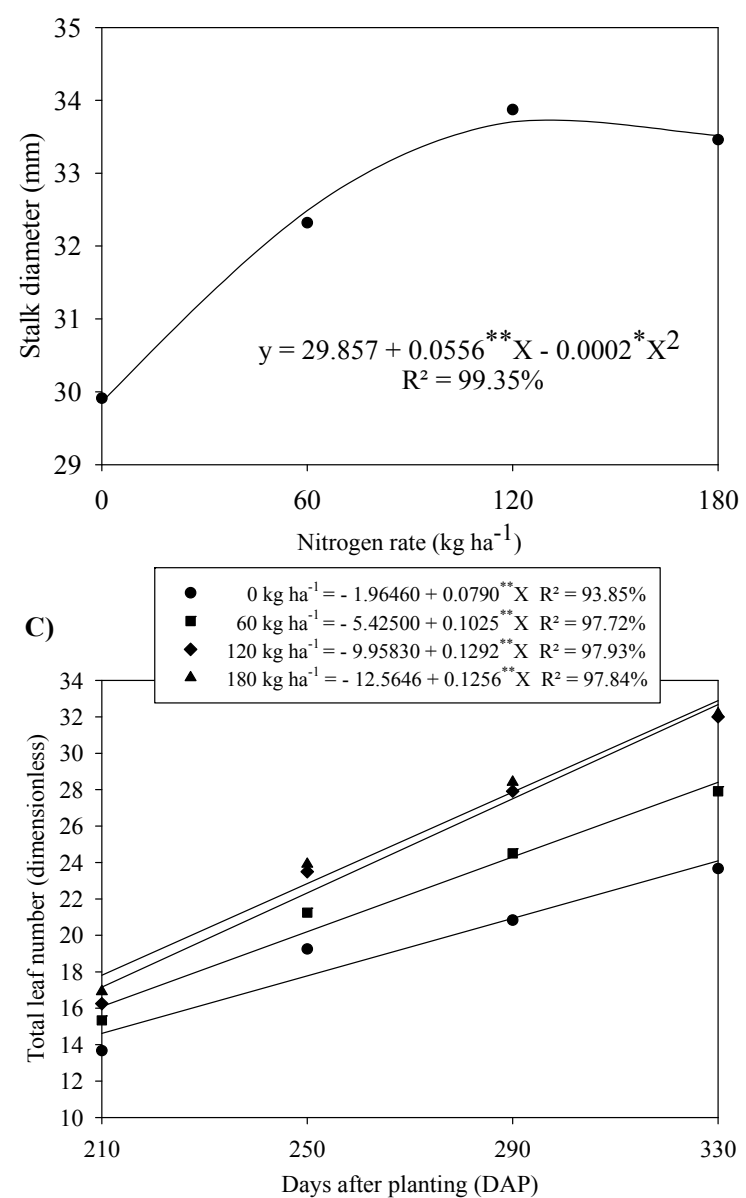

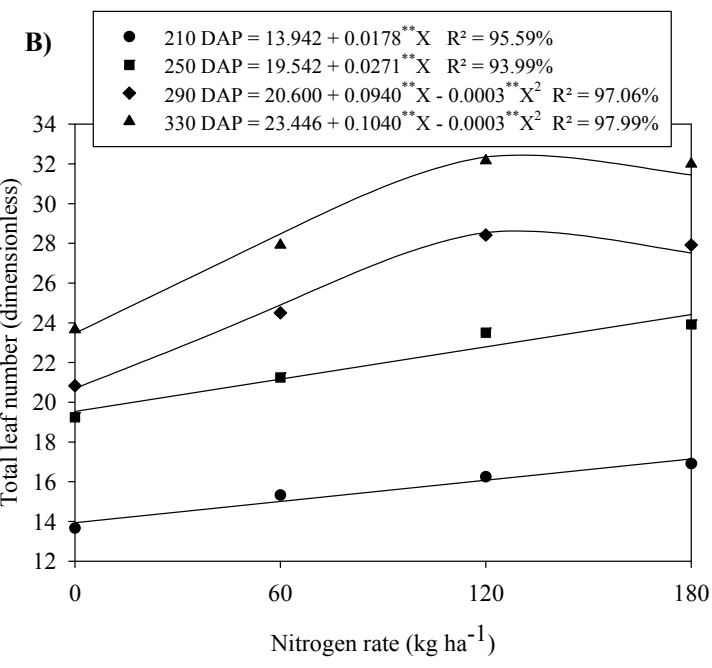

D)

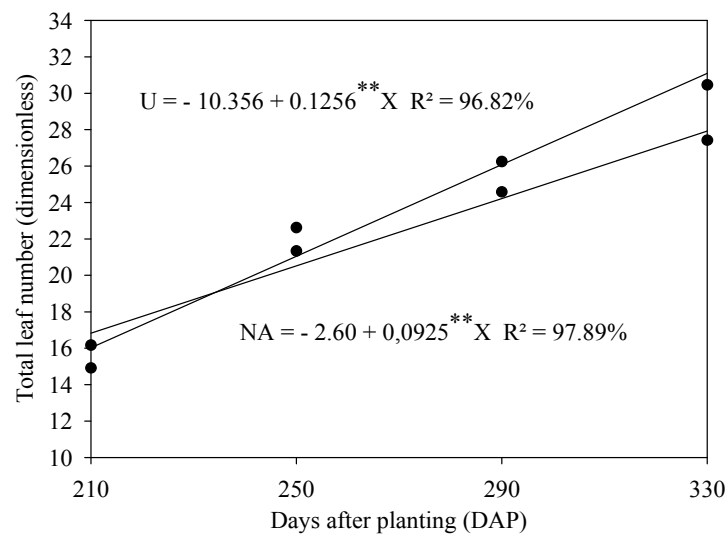

Figure 3. Stalk diameter (A) and total leaf number (B) in function of the nitrogen dose rate and total leaf number in function of the season of evaluation (C and D), Jataí-GO, Brazil, crop 2014/15

Note. $* *$ and $*$ significant respectively at $1 \%$ and $5 \%$ of probability according to test $\mathrm{F}$.

In the unfolding of the $\mathrm{N}$ rate factor within each season for GLN, there was an estimated linear increase of 1.66 and 1.40 leaves with $180 \mathrm{~kg} \mathrm{~N} \mathrm{ha}^{-1}$, corresponding to 17.54 and 13.13\%, respectively, for 210 and 250 DAP. At 290 and 330 DAP, it was observed that there was an estimated maximum quadratic increase of 13.90 and 13.81 leaf with 130.75 and $127.50 \mathrm{~kg} \mathrm{~N} \mathrm{ha}^{-1}$, corresponding to the increase of 3.42 leaves (24.60\%) and 3.25 leaf (23.53\%) (Figure $4 \mathrm{~A})$.

In the unfolding of the time factor within each N rate for GLN, there was an estimated linear increase of 3.20, 4.04, 5.95 and 4.52 green leaf at $330 \mathrm{DAP}$, corresponding to $28.60,36.33,39.93$ and $32.22 \%$, respectively, for $0,60,120$ and $180 \mathrm{~kg} \mathrm{~N} \mathrm{ha}^{-1}$ (Figure 4B).

For DLN as affectedby the $\mathrm{N}$ rate, it is observed that there was an estimated linear increase of 3.85 dead leaves with $180 \mathrm{~kg} \mathrm{~N} \mathrm{ha}^{-1}$, corresponding to $27.68 \%$ (Figure 4C). In the unfolding of the source factor within each season for DLN, it was observed that there was estimated linear increases of 7.09 and 10.22 dead leaves at 330 DAP, corresponding to 47.21 and $58.03 \%$, respectively, for ammonium nitrate and urea (Figure 4D). In the unfolding of the $\mathrm{N}$ rate factor within each time season for LA, it was observed that there was an estimated linear increase of 0.252 and $0.396 \mathrm{~m}^{-2}$ with $180 \mathrm{~kg} \mathrm{~N} \mathrm{ha}^{-1}$, corresponding to 31.15 and $35.54 \%$, respectively, at 250 and 290 DAP. At 330 DAP, it was observed that there was an estimated maximum quadratic increase of $1.46 \mathrm{~m}^{-2}$ with $135.0 \mathrm{~kg} \mathrm{~N}$ $\mathrm{ha}^{-1}$, corresponding to the increase of $0.547 \mathrm{~m}^{-2}$ (37.48\%) (Figure 4E).

In the unfolding of the time season factor within each $\mathrm{N}$ rate, it is observed that there was an estimated linear increase of $0.528,0.684,1.056,0.900 \mathrm{~m}^{-2}$, at $330 \mathrm{DAP}$, corresponding to $56.53,60.87,69.95$ and $61.90 \%$, respectively, for $0,60,120$ and $180 \mathrm{~kg} \mathrm{~N} \mathrm{ha}^{-1}$ (Figure $4 \mathrm{~F}$ ). 

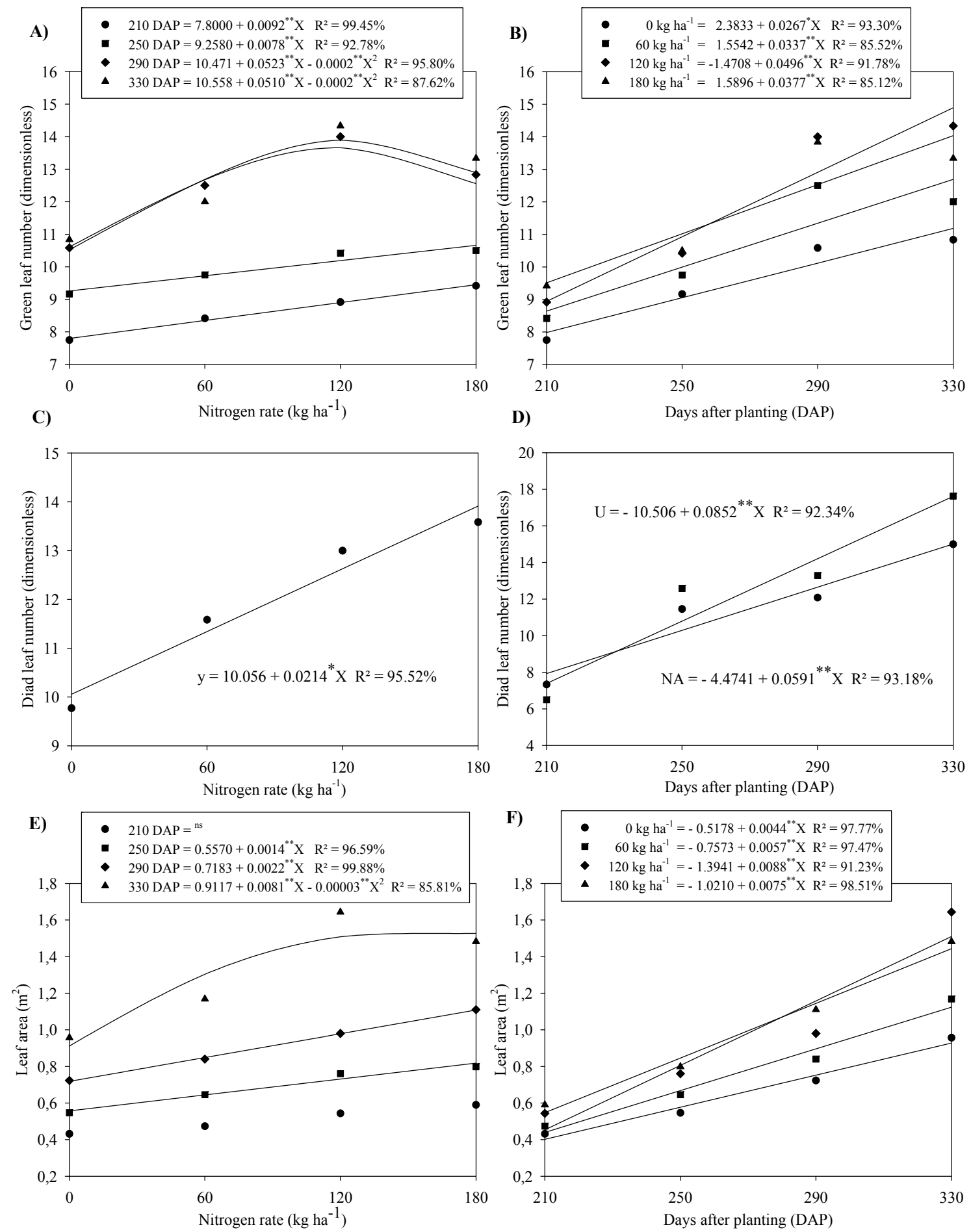

Figure 4. Green leaf number in function of the nitrogen dose (A), green leaf number in function of the season of evaluation (B), dead leaf number in function of the nitrogen dose (C), dead leaf number in function of the season of evaluation (D), leaf area in function of the nitrogen rate (E) end leaf area in function of the season of evaluation (F), Jataí-GO, Brazil, crop 2014/15

Note. ${ }^{\text {ns }}$ not significant, ${ }^{* *}$ and $*$ significant respectively at $1 \%$ and $5 \%$ of probability according to test $\mathrm{F}$. 
In the average test for unfolding of the source within each time season, the variable DLN as a function of the $\mathrm{N}$ source, it is observed that the source urea obtained the higher averages in relation to ammonium nitrate, with a percentage difference of 9.10 and $14.87 \%$, respectively, at 290 and 330 DAP (Table 3).

In the average test for unfolding of the source within each time season, the variable TLN as a function of the source of $\mathrm{N}$, it is observed that the urea source obtained the highest averages in relation to ammonium nitrate, with a percentage difference of 7.73, 5.70, 6.36 and 9.98\%, respectively, at 210, 250, 290 and 330 DAP (Table 3).

Table 3. Mean test for the variable diad leaf number (DLN) and total leaf number (TLN) in function of the source of nitrogen, Jataí-GO, Brazil, crop 2014/15

\begin{tabular}{|c|c|c|c|c|}
\hline Source of nitrogen & 210 DAP & 250 DAP & 290 DAP & 330 DAP \\
\hline \multicolumn{5}{|c|}{ Diad leaf number (DLN) } \\
\hline Urea & 6.50 & 12.58 & $13.29 \mathrm{a}$ & $17.62 \mathrm{a}$ \\
\hline Ammonium nitrate & 7.33 & 11.46 & $12.08 \mathrm{~b}$ & $15.00 \mathrm{~b}$ \\
\hline \multicolumn{5}{|c|}{ Total leaf number (TLN) } \\
\hline Urea & $16.17 \mathrm{a}$ & $22.62 \mathrm{a}$ & $26.25 \mathrm{a}$ & $30.46 \mathrm{a}$ \\
\hline Ammonium nitrate & $14.92 \mathrm{~b}$ & $21.33 \mathrm{~b}$ & $24.58 \mathrm{~b}$ & $27.42 b$ \\
\hline
\end{tabular}

Note. Means followed by the same letter in the columns do not differ according to Tukey test at $5 \%$ probability.

For PY in function of the $\mathrm{N}$ rate, it was observed that there was an estimated maximum quadratic increase of 38.33 $\mathrm{t} \mathrm{ha}^{-1}$ with $125.50 \mathrm{~kg} \mathrm{~N} \mathrm{ha}^{-1}$, corresponding to the increase of $15.75 \mathrm{t} \mathrm{ha}^{-1}$ (41.9\%) (Figure $5 \mathrm{~A}$ ). In relation to $\mathrm{SY}$ as a function of the $\mathrm{N}$ rate, it was observed that there was an estimated maximum quadratic increase of $173.04 \mathrm{tha}^{-1}$ with $125.33 \mathrm{~kg} \mathrm{~N} \mathrm{ha}^{-1}$, corresponding to the increase of $50.26 \mathrm{t} \mathrm{ha}^{-1}$ (29.04\%) (Figure 5B).

The TRS as a function of the $\mathrm{N}$ rate showed that there was an estimated maximum linear increase of $138.69 \mathrm{~kg} \mathrm{t}^{-1}$ of stalk with $180 \mathrm{~kg} \mathrm{~N} \mathrm{ha}^{-1}$, corresponding to the increase of (7.49\%) $9.66 \mathrm{~kg} \mathrm{t}^{-1}$ (Figure 5C).
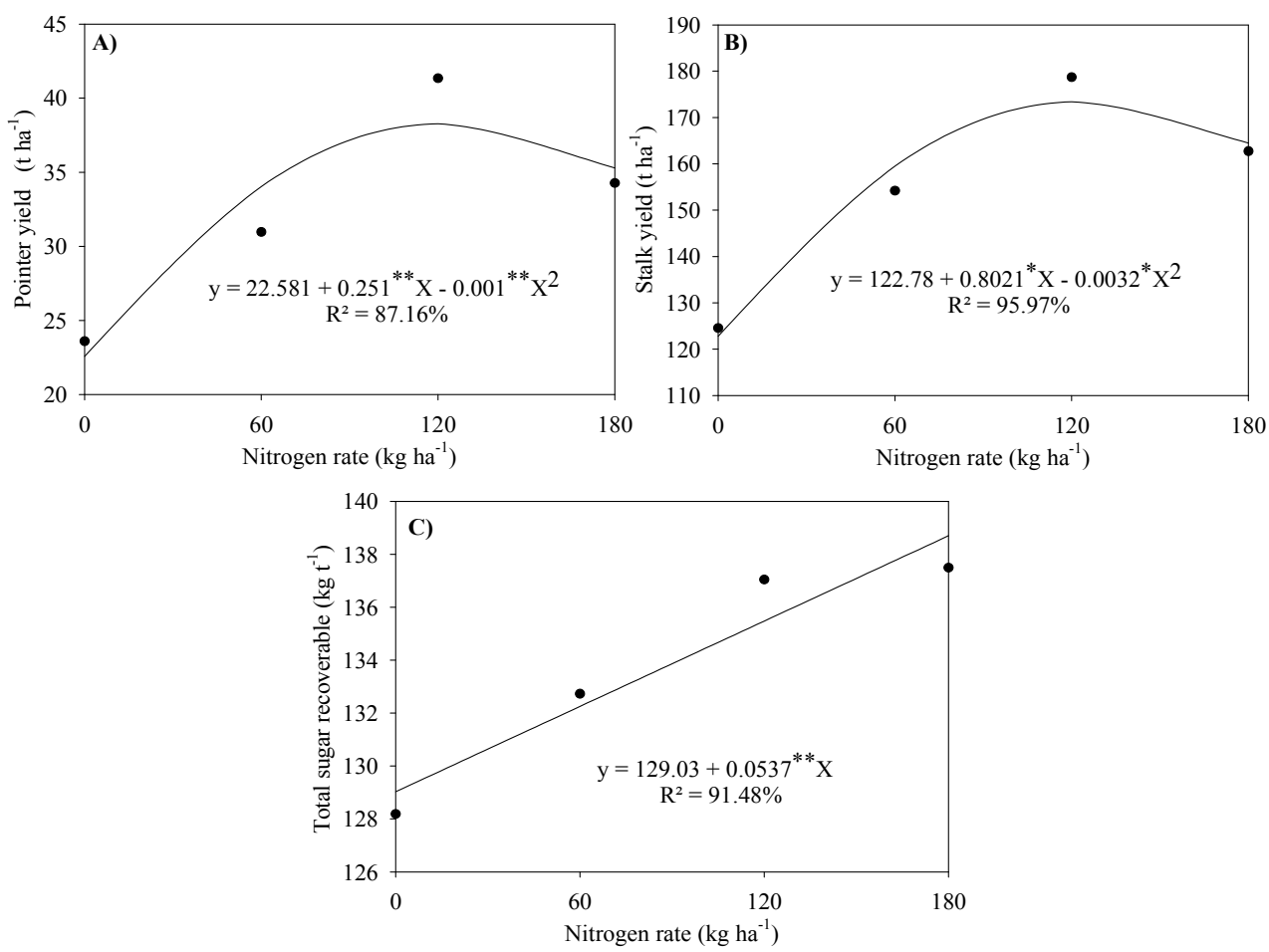

Figure 5. Pointer yield (A), stalk yield (B) and total sugar recoverable (C) as a function of the nitrogen dose, Jataí-GO, Brazil, crop 2014/15

Note. $* *$ and $*$ significant respectively at $1 \%$ and $5 \%$ of probability according to test $\mathrm{F}$. 


\section{Discussion}

In the growing season of $2014 / 15$, the rainfall precipitation at the experiment site was $1701.40 \mathrm{~mm}$ shown in Figure 1, close enough value for the development of sugarcane, which varies from 1500 to $2500 \mathrm{~mm}$, according to Doorenbos and Kassam (1994). However, it did not occur regularly throughout the harvest, predominating in the months of 10/2014 to 06/2015. Therefore the following two months after planting, 08/2014 to 10/2014 and at the end of the growth phase $06 / 2015$ to $08 / 2015$ the rainfall was insufficient, needing irrigation $(650.0 \mathrm{~mm}$, totaling the volume of $2351.40 \mathrm{~mm}$ during the growing cycle).

There are several factors to explain the low responses to $\mathrm{N}$ by cane-plant, such as the mineralization of soil organic matter and crop residues remains during soil rotation in the cane field (Cantarella et al., 2007). Other justifications for the low response of the cane-plant to $\mathrm{N}$ include greater vigor of the root system of cane-plant compared to that of the ratoon, the improvement of the soil fertility associated with liming and fertilization made in the reforestation of the cane field, the biological $\mathrm{N}$ fixation, the lower initial nutrient demand of the cane-plant, the losses of $\mathrm{N}$ fertilizers by leaching and the contribution of the $\mathrm{N}$ stocked on the seedpiece stalk (Vitti et al., 2008; Urquiaga et al., 2012).

Recent studies have shown low sugarcane response to nitrogen fertilization (Otto et al., 2013; Mariano, 2015), especially in areas managed in rotation with legumes or with the use of organic residues such as vinasse and filter cake. In one of the areas evaluated by Otto et al. (2013), with a history of vinasse application, there was no response of sugarcane to the nitrogen fertilization of ratoon in three consecutive growing seasons, indicating that the mineralization of the soil organic matter possible supplied the $\mathrm{N}$ demand by the crop.

Oliveira et al. (2010) in this same phase of growth, in study with early ripening varieties RB872552 and RB863129 obtained, respectively, the highest PH with values of 3.10 and $2.91 \mathrm{~m}$, these results shows a highest growth of stalk despite being compared to other varieties.

The results obtained corroborate with Moura et al. (2005), who consider SD values above $22 \mathrm{~mm}$ for irrigated sugarcane.

The increase of the stalk diameter in accordance with the evaluation phases was also verified in other studies; however, followed by the reduction of this morphological parameter from the 291 days after the cut (Oliveira et al., 2010; Arantes, 2012; Rhein, 2012), a fact that did not affect the results found, because there was no decrease in stalk diameter over time.

Results found by Silva et al. (2014) in Brazilian cerrado, under an Oxisol of clay texture, the IN had a large initial increase to 210 DAP, due to the sugarcane phase, but reached their maximum values around 270 to 300 DAP. For stalk diameter (SD), high initial growth was observed, extending up to 210 DAP. An increase of $34 \%$ in this period was observed, with $32.6 \mathrm{~mm}$, being found at 210 DAP. However, the maximum SD response was reached at 330 DAP, with a mean of $37.9 \mathrm{~mm}$.

Silva et al. (2008) consider HP and SD as one of the components for the formation of sugarcane potential production, and they also add that irrigation enables the responsive varieties to better express their genetic potential.

For Diola and Santos (2010) the stalk growth phase starts from 120 DAP and lasts up to 270 DAP, in a 12-month culture; this is the most important phase of the crop, because it is when the stalk formation occurs, which results in production; irrigation, fertilization, heat, humidity and ideal climatic conditions favor stretching; the maturation stage in cane-plant cultivation lasts from approximately 270 to 360 DAP and the synthesis and rapid accumulation of sugar occur during this phase, which is why vegetative growth is reduced.

Results found by Cunha et al. (2016), in a Brazilian cerrado, under a clayey Oxisol, studying the effect of nitrogen fertirrigation, shows greater promotion of vegetative growth of irrigated sugarcane first ratoon (RB85-5453), especially in the periods of 270, 300 and 330 days after the cut, corroborating with the results found in this study despite the fact that it was cane-plant.

In $\mathrm{SD}$ as affected by the $\mathrm{N}$ rate, it is observed that there was an estimated maximum quadratic increase of 33.72 $\mathrm{mm}$ with $139.0 \mathrm{~kg} \mathrm{~N} \mathrm{ha}^{-1}$, corresponding to (11.45\%) $3.86 \mathrm{~mm}$ (Figure 3A). Uribe (2010) did not observe increase in sugarcane stalk diameter with elevation of $\mathrm{N}$ rate under irrigated grown.

In the variance analysis, it was observed that the variables green leaf number (GLN), total leaf number (TLN) and leaf area (LA) were significant for the interaction between dose and time. The total leaf number variable (TLN) was also significant along with diad leaf number (DLN) for the interaction between source and season. However, it has not been possible to determine the effect of N in cane-plant. Silva et al. (2015) in study with irrigated sugarcane 
in a Brazilian Oxisol, found a significant effect on leaf number and leaf area for nitrogen rate and water reed in cane-plant.

The GLN found in this study is according to obtained by Magro et al. (2011), who state that the mature sugarcane plant has a number of green leaf per stalk around ten, depending on the variety and growth conditions.

For Pincelli (2010) the variable number of green leaf is characterized as important, because through this one can verify the photosynthetic efficiency of the plant in front of the proposed stresses. The same authors observed that under ideal conditions of moisture in the substrate there was an increase in the number of green leaf in all cultivars, which were significantly higher than the values under water restriction at 28 and 56 days after treatment (DAT). For this variable it was also possible to identify differential responses for cultivars under water deficiency, that is, cultivars SP81-3250 and SP83-2847 presented 5 and 7 leaves, respectively, at 56 DAT, and cultivars RB85-5453 and RB72454 both with three leaves under the same period.

Machado et al. (2009) observed that two evaluated genotypes presented a significant reduction in the amount of green leaves, due to the water deficit. Smit and Singels (2006) reported that leaf senescence is responsive to water deficit and occurs after reduction in leaf emergence.

Leaf death is a natural process of plant senescence (Diola \& Santos, 2010; Marafon, 2012), when it reaches its definitive size, the plant enters the senescence phase and shoots maturity, with less interception of light energy, decrease in the accumulation of dry matter and translocation of sugars to the storage organs. However, this process can be accelerated due to the reduction of GL reported for plants with water deficit (Pimentel, 2004) and attributed to the strategy to reduce transpiration surface and metabolic expenditure for tissue maintenance (Inman-Bamber et al., 2008). If leaf senescence and leaf sprouting are responses to genotype-dependent water deficit (Smit \& Singels, 2006), the number of green leaf can be used as an indicator of the effect of water deficit on sugarcane, according to suggests Inman-Bamber (2004). Another factor that may contribute to the increase of NFM is the nitrogen deficiency that can reduce the photosynthetic capacity (Meinzer \& Zhu, 1998).

Results found by Silva et al. (2014) show a higher increase in LA between 240 and 300 DAP, and there was still an exponential growth as a function of the DAP for irrigated sugarcane.

Results found by Pincelli (2010) indicated reduction of leaf area under water deficiency in all cultivars, however, cultivars SP81-3250 and SP83-2847 presented higher leaf area under water shortage than cultivars RB85-5453 and RB72454 at the end of the evaluation period, but this period lasted only 56 DAT.

For Oliveira et al. (2007) the study of leaf area in sugarcane cultivars allows correlating it with its productive potential, whether in dry mass, sugar quantity or growth rates. The development of leaf area is critical for the establishment of the crop and the closing of the canopy and maximization of the radiation interception in search of crop productivity (Sinclair et al., 2004). Studies have shown that the leaf area of sugarcane increases during the period of high crop growth (Teixeira et al., 2012).

In the analysis of variance, it was observed that the number of industrializable tillers was not significant, since stalk yield (SY), pointer yield (PY) and total recoverable sugar (TRS) were significant for the $\mathrm{N}$ rate factor. Roy et al. (2006) and Franco et al. (2010), evaluating the productivity of the cane-plant in relation to nitrogen fertilization, verified that there was an increase in productivity, and also add that the high yields are often associated with high $\mathrm{N}$ rates.

In recent research, productivity responses have been found as a function of nitrogen fertilization, Fortes et al. (2013) found in a dystrophic Red Latosol a linear response of shoot yield at doses of $\mathrm{N}_{-} \mathrm{NH}_{4} \mathrm{NO}_{3}(0,50,100$ and $150 \mathrm{~kg} \mathrm{~N} \mathrm{ha}^{-1}$ ). In other studies, with different conditions, in sandy soil (Florida, USA), McCray et al. (2014) found quadratic responses to $\mathrm{N}$ rate as urea higher than the current $\mathrm{N}$ recommendation $\left(202 \mathrm{~kg} \mathrm{~N}^{-1}\right)$. These authors add that the effect of $\mathrm{N}$ response on stalk yield can be explained physiologically by changes in plant growth, number of tillers, biomass production and, consequently, the amount of stored sugar. Bologna-Campbell (2007) and Franco et al. (2010) refer the response of the cane-plant to the nitrogen fertilization to several factors such as the soil tillage type, the $\mathrm{N}$ stock in the organic matter, soil texture and also the rotation history with green manures.

These results are in agreement with those found by Sánchez-Román et al. (2015), in cerrado environment, observed an increase of TRS as a function of nitrogen fertilization in the irrigated treatments, corresponding to $5.11 \%$.

Considering irrigated environments in Brazil, studies carried out by Teodoro (2011) in Rio Largo-AL, and by Kölln (2012) in Jaú - SP, confirmed the positive responses of sugarcane to the application of $\mathrm{N}$ in irrigated management. The results obtained in these studies contrast with the N-response curves obtained in recent studies with sugarcane under rainfied conditions, in which maximum yields were reached at doses of 100 to $120 \mathrm{~kg} \mathrm{~N} \mathrm{ha}^{-1}$ 
(Vitti et al., 2007). This is a fact that indicates that nitrogen fertilization recommendations should be higher for environments with low water restriction (irrigated environments), compared to rainfed environments, because the potentials of crop productivity are higher (Gava et al., 2010; Oliveira et al., 2011; Andrade Júnior et al., 2012).

\section{Conclusions}

The increases observed in the variables plant height, stalk diameter, training length and training number in the evaluated period were, respectively, 25.97, 8.91, 19.88 and $33.24 \%$.

The nitrogen source interferes in the number of dead leaf and total leaf number, and the use of urea gives the larger number of leaves.

Ammonium nitrate contributes regardless of dose or time for less reduction of the training length.

The increase of the nitrogen rate increases the number of green leaf, dead leaf number and leaf area linearly up to 250 DAP. At 290 and 330 DAP the maximum increase is observed at the average dose of $144.65 \mathrm{~kg} \mathrm{~N} \mathrm{ha}^{-1}$.

Regardless of the source applied, the dose of $125 \mathrm{~kg} \mathrm{~N} \mathrm{ha}^{-1}$, provided higher yield of biomass, both of stem and pointers to sugarcane. The increase of the nitrogen rate proportionate linear increases in the total recoverable sugar, However, with lower intensity per unit of $\mathrm{N}$ between the doses of 120 to $180 \mathrm{~kg} \mathrm{~N} \mathrm{ha}^{-1}$.

\section{Acknowledgements}

The authors thank the National Council for Scientific and Technological Development $(\mathrm{CNPq})$, the Coordination for the Improvement for Higher Level Personnel (CAPES), the Research Support Foundation of the State of Goiás (FAPEG), the Ministry of Science, Technology, Innovation and Communications (MCTIC), the Raízen Plant Jataí unit, and the Federal Institute of Education, Science and Technology Goiano (IF Goiano)-Campus Rio Verde for the financial and structural support to conduct this study.

\section{References}

Allen, R. G., Jensen, M. E., Wright, J. L., \& Burman, R. D. (1989). Operational estimates of reference evapotranspiration. Agronomy Journal, 81, 650-662. https://doi.org/10.2134/agronj1989.0002196200810 0040019x

Andrade Júnior, A. S., Bastos, E. A., Ribeiro, V. Q., Duarte, J. A. L., Braga, D. L., \& Noleto, D. H. (2012). Níveis de água, nitrogênio e potássio por gotejamento subsuperficial em cana-de-açúcar. Pesquisa Agropecuária Brasileira, 47(1), 76-84. https://doi.org/10.1590/S0100-204X2012000100011

Arantes, M. T. (2012). Potencial produtivo de cultivares de cana-de-açúcar sob os manejos irrigado e sequeiro (65f., Dissertation, Faculdade de Ciências Agronômicas da UNESP, Campus de Botucatu).

Benincasa, M. M. P. (2003). Análise de crescimento de plantas: Noções básicas (2nd ed., p. 41). Jaboticabal: FUNEP.

Bologna-Campbell, I. (2007). Balanço de nitrogênio e enxofre no sistema solo-cana-de-açúcar no ciclo de cana-planta, 2007 (p. 112, Thesis, Escola Superior de Agricultura Luiz de Queiroz).

Cabral Filho, F. R., Vieira, G. S., Silva, N. F., Cunha, E. S., Santos, L. N. S., Rodrigues, C. R., ... Soares, F. A. L. (2018). Sugarcane vinasse cations dynamics in cerrado soils, Brazil. Sugar Tech, 20, 1-9. https://doi.org/ 10.1007/s12355-018-0620-4

Cantarella, H., Trivelin, P. C. O., \& Vitti, A. C. (2007). Nitrogênio e enxofre na cultura da cana-de-açúcar. In T. Yamada, S. R. S. Abdalla, \& G. C. Vitti (Eds.), Nitrogênio e Enxofre na Agricultura Brasileira (pp. 349-412). Piracicaba: International Plant Nutrition Institute.

Cunha, F. N., Silva, N. F., Sousa, A. E. C., Teixeira, M. B., Soares, F. A. L., \& Vidal, V. M. (2016). Yield of sugarcane submitted to nitrogen fertilization and water depths by subsurface drip irrigation. Revista Brasileira de Engenharia Agrícola e Ambiental, 20(9), 841-846. https://doi.org/10.1590/1807-1929/agriambi. v20n9p841-846

Dalri, A. B., \& Cruz, R. L. (2008). Produtividade da cana-de-açúcar fertirrigada com N e K via gotejamento subsuperficial. Irriga, 28(3), 516-524.

Dantas Neto, J., Figueirêdo, J. L. C., Farias, C. H. A., Azevedo, H. M. De, \& Azevedo, C. A. V. (2006). Resposta da cana-de-açúcar, primeira soca, a níveis de irrigação e adubação de cobertura. Revista Brasileira de Engenharia Agrícola e Ambiental, 10, 283-288. https://doi.org/10.1590/S1415-43662006000200006

Diola, V., Santos, F., \& Fisiologia. (2010). Cana-de-açúcar: Bioenergia, açúcar e álcool-tecnologia e perspectivas (pp. 25-49). Viçosa: Suprema Gráfica e Editora Ltda. 
Doorenbos, J., \& Kassam, A. H. (1994). Efeito da água no rendimento das culturas (Estudos de FAO, Irrigação e Drenagem, 33, p. 306). Campina Grande: UFPB.

Epstein, E., \& Bloom, A. J. (2006). Mineral nutrition of plants: Principles and perspectives (p. 400). Sunderland: Sinauer Associates.

Farias, C. H. A., Fernandes, P. D., Azevedo, H. M., \& Dantas Neto, J. (2008). Índices de crescimento da cana-de-açúcar irrigada e de sequeiro no Estado da Paraíba. Revista Brasileira de Engenharia Agrícola e Ambiental, 12, 356-362. https://doi.org/10.1590/S1415-43662008000400004

Fortes, C., Trivelin, P. C. O., Vitti, A. C., Otto, R., Franco, H. C. J., \& Faroni, C. E. (2013). Stalk and sucrose yield in response to nitrogen fertilization of sugarcane under reduced tillage. Pesquisa Agropecuária Brasileira, 48(1), 88-96. https://doi.org/10.1590/S0100-204X2013000100012

Franco, H. C. J., Otto, R., Faroni, C. E., Vitti, A. C., Oliveira, E. C. A., \& Trivelin, P. C. O. (2011). Nitrogen in sugarcane derived from fertilizer under Brazilian field conditions. Field Crops Research, 121, 29-41. https://doi.org/10.1016/j.fcr.2010.11.011

Franco, H. C. J., Trivelin, P. C. O., Faroni, C. E., Vitti, A. C., \& Otto, R. (2010). Stalk yield and technological attributes of planted cane as related to nitrogen fertilization. Scientia Agricola, 67(5), 579-590. https://doi.org/10.1590/S0103-90162010000500012

Gava, G. J. C., Kölln, O. T., Uribe, R. A. M., Trivelin, P. C. O., \& Cantarella, H. (2010). Interação entre água e nitrogênio na produtividade de cana-de-açúcar (Saccharum sp.). In C. A. Crusciol (Org.), Tópicos em ecofisiolgia da cana-de-açúcar (1st ed., Vol. 1, pp. 49-66). Botucatu: FEPAF.

Gilbert, R. A., Shine Júnior, J. M., Miller, J. D., \& Rainbolt, C. R. (2006). The effect genotype, environmental and time of harvest on sugarcane yields in Florida, USA. Field Crops Research, 95, 156-170. https://doi.org/ 10.1016/j.fcr.2005.02.006

Hermann, E. R., \& Câmara, G. M. S. (1999). Um método simples para estimar a área foliar de cana-de-açúcar. Revista da STAB, 17, 32-34.

Holst, J., Brackina, R., Robinsona, N., Lakshmananb, P., \& Schmidta, S. (2012). Soluble inorganic and organic nitrogen in two Australian soils under sugarcane cultivation. Agriculture, Ecosystems and Environment, 155, 16-26. https://doi.org/10.1016/j.agee.2012.03.015

Inman-Bamber, N. G. (2004) Sugarcane water stress criteria for irrigation and drying off. Field Crops Research, 89, 107-122. https://doi.org/10.1016/j.fcr.2004.01.018

Inman-Bamber, N. G., Bonnett, G. D., Spillman, M. F., Hewitt, M. L., \& Jackson, J. (2008). Increasing sucrose accumulation in sugarcane by manipulating leaf extension and photosynthesis with irrigation. Australian Journal of Agricultural Research, 59, 13-26. https://doi.org/10.1071/AR07167

Kölln, O. T. (2012). Interação entre os estresses de nitrogênio e disponibilidade hídrica no fracionamento isotópico de ${ }^{13}$ C e na produtividade em soqueira de cana-de-açúcar (p. 104, Dissertation, Centro de Energia Nuclear na Agricultura, Universidade de São Paulo, Piracicaba).

Köppen, W., \& Geiger, R. (1928). Klimate der Erde. Gotha: Verlag Justus Perthes.

Korndörfer, C. M., Korndörfer, G. H., \& Cardoso, K. (2002). Aplicação do silicato de cálcio na recuperação de pastagem degradada de Brachiaria decumbens. Proceedings of Reunião brasileira de fertilidade do solo e nutrição de plantas, 25, Rio de Janeiro (pp. 8-11). Rio de Janeiro: SBCS.

Lelis Neto, J. A. (2012). Aplicação de vinhaça via gotejamento subsuperficial e seus efeitos nos perfis de distribuição iônico e atributos físicos e químicos de um Nitossolo (p. 138, Thesis, Escola Superior de Agricultura "Luiz de Queiroz", Piracicaba).

Machado, R. S., Ribeiro, R. V., Marchiori, P. E. R., Machado, D. F. S. P., Machado, E. C., \& Landell, M. G. A. (2009). Respostas biométricas e fisiológicas ao déficit hídrico em cana-de-açúcar em diferentes fases fenológicas. Pesquisa Agropecuária Brasileira, 44(12), 1575-1582. https://doi.org/10.1590/S0100-204X20 09001200003

Magro, F., Takao, J., Camargo, G. P. E., \& Takamatsu, S. Y. (2011). Biometria em cana-de-açúcar (p. 18). Universidade de São Paulo, Escola Superior de Agricultura "Luiz de Queiroz”. 
Mariano, E., Leite, J. M., Megda, M. X. V., Torres-Dorante, L., \& Trivelin, P. C. O. (2015). Influence of nitrogen form supply on soil mineral nitrogen dynamics, nitrogen uptake, and productivity of sugarcane. Agronomy Journal, 107, 641-650. https://doi.org/10.2134/agronj14.0422

Maschio, R. (2011). Produtividade da água em biomassa e energia para 24 variedades de cana-de-açúcar (p. 87, Dissertation, Escola Superior de Agricultura “Luiz de Queiroz").

Mccray, J. M., Morgan, K. T., Baucum, L., \& Ji, S. (2014). Sugarcane yield response to nitrogen on sand soils. Agronomy Journal, 106, 1461-1469. https://doi.org/10.2134/agronj13.0513

Meinzer, F. C., \& Zhu, J. (1998). Nitrogen stress reduces the efficiency of the $\mathrm{C} 4 \mathrm{CO}_{2}$ concentrating system, and therefore quantum yield, in Saccharum (sugarcane) species. Journal of Experimental Botany, 49, 1227-1234. https://doi.org/10.1093/jexbot/49.324.1227

Moura, M. V. P. S., Farias, C. H. A., Azevedo, C. A. V., Dantas Neto, J., Azevedo, H. M., \& Pordeus, R. M. (2005). Doses de adubação nitrogenada e potássica em cobertura na cultura da cana-de-açúcar, primeira soca, com e sem irrigação. Ciência e Agrotecnologia, 29(4), 753-760. https://doi.org/10.1590/S1413-705420050004 00006

Oliveira, E. C. A., Freire, F. J., Oliveira, A. C., Simões Neto, D. E., Rocha, A. T., \& Carvalho, L. A. (2011). Produtividade, eficiência de uso da água e qualidade tecnológica de cana-de-açúcar submetida a diferentes regimes hídricos. Pesquisa Agropecuária Brasileira, 46(6), 617-625. https://doi.org/10.1590/S0100-204X2011 000600007

Oliveira, E. C. A., Freire, F. J., Oliveira, A. C., Simões Neto, D. E., Rocha, A. T., \& Carvalho, L. A. (2011). Produtividade, eficiência de uso da água e qualidade tecnológica de cana-de-açúcar submetida a diferentes regimes hídricos. Pesquisa Agropecuária Brasileira, 46(6), 617-625.

Oliveira, E. C. A., Oliveira, R. I., Andrade, B. M. T., Freire, F. J., Lira Júnior, M. A., \& Machado, P; R. (2010). Crescimento e acúmulo de matéria seca em variedades de cana-de-açúcar cultivadas sob irrigação plena. Revista Brasileira de Engenharia Agrícola e Ambiental, 14(9), 951-960.

Oliveira, R. A., Daros, E., Zambon, J. L. C., Weber, H., Ido, O. T., Bespalhok-Filhos, J. C., ... Silva, D. K. T. (2007). Área foliar em três cultivares de cana-de-açúcar e sua correlação com a produção de biomassa. Pesq. Agropec. Trop, 37(2), 71-76.

Oliveira, R. C., Cunha, F. N., Silva, N. F., Teixeira, M. B., Soares, F. A. L., \& Megguer; C. A. (2014). Productivity of fertirrigated sugarcane in subsurface drip irrigation system. African Journal of Agricultural Research, 9(11), 993-1000. https://doi.org/10.5897/AJAR2013.7829

Otto, R., Mulvaney, R. L., Khan, S. A., \& Trivelin, P. C. O. (2013). Quantifying soil nitrogen mineralization to improve fertilizer nitrogen management of sugarcane. Biology and Fertility of Soils, 1, 1-12. https://doi.org/ 10.1007/s00374-013-0787-5

Pimentel, C. (2004). A relação da planta com a água (p. 191). Seropédica: EDUR.

Pincelli, R. P. (2010). Tolerância à deficiência hídrica em cultivares de cana-de-açúcar avaliada por meio de variáveis morfofisiológicas (65 f., Dissertation, Universidade Estadual Paulista, Faculdade de Ciências Agronômicas, Botucatu).

Pinheiro, E. F. M., Lima, E., Ceddia, M. B., Urquiaga, S., Alves, B. J. R., \& Boddey, R. M. (2010). Impact of pre-harvest burning versus trash conservation on soil carbon and nitrogen stocks on a sugarcane plantation in Brazilian Atlantic forest region. Plant and Soil, 333, 71-80. https://doi.org/10.1007/s11104-010-0320-7

Prado, R. M., \& Pancelli, M. A. (2008). Resposta de soqueiras de cana-de-açúcar à aplicação de nitrogênio em sistema de colheita sem queima. Bragantia, 67(4), 951-959. https://doi.org/10.1590/S0006-87052008000 400018

Raij, B., Andrade, J. C., Cantarella, H., \& Quaggio, J. A. (2001). Análise química para avaliação da fertilidade de solos tropicais (p. 284). Campinas: Instituto Agronômico.

Resende, A. S., Santos, A., Xavier, R. P., Coelho, C. H., Gondim, A., Oliveira, O. C., ... Urquiaga, S. (2006). Efeito da queima da palhada da cana-de-açúcar e de aplicações de vinhaça e adubo nitrogenado em características tecnológicas da cultura. Revista Brasileira de Ciência do Solo, 30, 937-941. https://doi.org/10.1590/S0100-06832006000600003

Resende, A. S., Xavier, R. P., Oliveira, O. C., Urquiaga, S., Alves, B. J. R., \& Boddey, R. M. (2006). Long-term effects of pre-harvest burning and nitrogen and vinasse applications on yield of sugar cane and soil carbon 
and nitrogen stocks on a plantation in Pernambuco, N.E. Brazil. Plant and Soil, 281, 339-351. https://doi.org/10.1007/s11104-005-4640-y

Rhein, A. F. L. (2012). Produtividade e qualidade da cana-de-açúcar sob doses de nitrogênio via fertirrigação subsuperficial por gotejamento (p. 117, Thesis, Universidade estadual paulista "Júlio de Mesquita Filho", UNESP, Botucatu, SP).

Rossetto, R. (2012). Maturação da cana-de-açúcar. Retrieved from http:/www.agencia.cnptia.embrapa.br/ gestor/cana-de-acucar/arvore/CONTAG01 90 22122006154841.html

Rossetto, R., Dias, F. L. F., Landell, M. G. A., Cantarella, H., Tavares, S., Vitti, A. C., \& Perecin, D. (2010). N and $\mathrm{K}$ fertilisation of sugarcane ratoons harvested without burning. Proceedings of International Sugarcane Technologists Congress, 27, Vera Cruz (pp. 1-8). Vera Cruz: ISSCT.

Rossi, C. Q., Pereira, M. G., Loss, A., Gazolla, P. R., Perin, A., \& Anjos, L. H. C. (2013). Changes in soil C and $\mathrm{N}$ distribution assessed by natural ${ }^{13} \mathrm{C}$ and ${ }^{15} \mathrm{~N}$ abundance in a chronosequence of sugarcane crops managed with pre-harvest burning in a cerrado area of Goiás, Brazil. Agriculture, Ecosystems and Environment, 170, 36-44. https://doi.org/10.1016/j.agee.2013.03.008

Roy, R. N., Finck, A., Blair, G. J., \& Tandon, H. L. S. (2006). Plant nutrition for food security. A guide for integrated nutrient management. FAO Fertilizer and Plant Nutrition Bulletin, 16 (p. 249). Rome: Food and Agriculture Organization of the United Nations.

Sánchez-Román, R. M., Silva, N. F. Da, Cunha, F. N., Teixeira, M. B., Soares, F. A. L., \& Ribeiro, P. H. P. (2015). Produtividade da cana-de-açúcar submetida a diferentes reposições hídricas e nitrogênio em dois ciclos. Irriga, 1(1), 198-210. https://doi.org/10.15809/irr iga.2015v1n1p198

Santos, H. G., Jacomine, P. K. T., Anjos, L. H. C., Oliveira, V. A., Lumbreras, J. F., Coelho, M. R., ... Oliveira, J. B. (2013). Sistema brasileiro de classificação de solos (3rd ed., p. 353). Brasília: Embrapa.

SAS Institute Incorporation. (2001). The SAS-System for Windows release 8.02 (TS2M0). SAS Institute Inc. Cary, NC, USA.

Silva, C. T. S., Azevedo, H. M., Azevedo, C. A. V., Dantas Neto, J., Carvalho, C. M., \& Gomes Filho, R. R. (2009). Crescimento da cana-de-açúcar com e sem irrigação complementar sob diferentes níveis de adubação de cobertura nitrogenada e potássica. Revista Brasileira de Agricultura Irrigada, 3(1), 3-12. https://doi.org/ 10.7127/rbai.v3n100012

Silva, M. A., Silva, J. A. G., Enciso, J., Sharma, V., \& Jifon, J. (2008). Yield components as indicators of drought tolerance of sugarcane. Scientia Agricola, 65, 620-627. https://doi.org/10.1590/S0103-90162008000600008

Silva, M. A., Soares, R. A. B., Landell, M. G. A., \& Campana, M. P. (2008). Agronomic performance of sugarcane families in response to water stress. Bragantia, 67, 656-661. https://doi.org/10.1590/S0006-870 52008000300014

Silva, N. F. (2014). Cultivo da cana-de-açúcar submetida a diferentes lâminas de irrigação e fertirrigação nitrogenada via gotejamento subsuperficial (p. 86, Dissertation, Agronomia. Instituto Federal Goiano, Campus Rio Verde, GO).

Silva, N. F., Cunha, F. N., Oliveira, R. C., Moura, L. M. F., Moura, L. C., \& Teixeira. M. B. (2014). Crescimento da cana-de-açúcar sob aplicação de nitrogênio via gotejamento subsuperficial. Revista Brasileira de Agricultura Irrigada, 8(1), 1-11. https://doi.org/10.7127/rbai.v8n100188

Silva, N. F., Cunha, F. N., Teixeira, M. B., Soares, F. A. L., \& Moura, L. C. (2015). Crescimento vegetativo da cana-de-açúcar submetida a lâminas de irrigação e fertirrigação nitrogenada via gotejamento subsuperficial. Revista Brasileira de Agricultura Irrigada, 9(2), 79-90. https://doi.org/10.7127/rbai.v9n200274

Sinclair, T. R., Gilbert, R. A., Perdomo, R. E., Shine, J. R., Powell, G., \& Montes, G. (2004). Sugarcane leaf area development under field conditions in Florida, USA. Field Crops Research, 88(2-3), 171-178. https://doi.org/ 10.1016/j.fcr.2003.12.005

Singh, S. N., Singh, A. K., Malik, J. P. S., Kumar, R., \& Sharma, M. L. (2012). Cultura-practice packages and trash management effects on sugarcane ratoons under sub-tropical climatic conditions of India. Journal of Agricultural Science, 150, 237-247. https://doi.org/10.1017/S0021859611000499

Smit, M. A., \& Singels, A. (2006). The response of surgarcane canopy development to water stress. Field Crops Research, 98, 91-97. https://doi.org/10.1016/j.fcr.2005.12.009 
Soil Survey Staff. (2010). Keys to soil taxonomy (11th ed., p. 338). Washington: United States Department of Agriculture, Natural Resources Conservation Service.

Sousa, D. M. G., \& Lobato, E. (Eds). (2004). Cerrado: Correção do solo e adubação (2nd ed., p. 416). Brasília: Embrapa Informação Tecnológica/Embrapa-CPA.

Teodoro, I. (2011). Respostas técnico-econômicas da cana-de-açúcar a niveis de irrigação e adubação nitrogenada (p. 100, Thesis, Universidade Federal de Campina Grande, Campina Grande, Paraíba).

Trivelin, P. C. O., Franco, H. C. J., Otto, R., Ferreira, D. A., Vitti, A. C., Fortes, C., ... Cantarella, E. (2013). Impact of sugarcane trash on fertilizer requirements for São Paulo, Brazil. Scientia Agricola, 70, 345-352. https://doi.org/10.1590/S0103-90162013000500009

Uribe, R. A. M. (2010). Produtividade e estimativa do acúmulo de biomassa em soqueira de cana-deaçúcar irrigada por gotejamento com diferentes doses de N-fertilizante (67f., Thesis, Universidade Estadual Paulista Júlio de Mesquita Filho, Botucatu).

Urquiaga, S., Xavier, R. P., Morais, R. F., Baptista, R. B., Schultz, N., Leite, J. M., ...Boddey, R. M. (2012). Evidence from field nitrogen balance and ${ }^{15} \mathrm{~N}$ natural abundance data for the contribution of biological $\mathrm{N}_{2}$ fixation to Brazilian sugarcane varieties. Plant and Soil, 356, 5-21.

Vitti, A. C., Cantarella, H., Trivelin, P. C. O., \& Rosseto, R. (2008). Nitrogênio. In L. L. Dinardo-Miranda, A. C. M. Vasconcelos, \& M. G. A. Landell (Eds.), Cana-de-açúcar (p. 882). Campinas: IAC.

Vitti, A. C., Franco, H. C. J., Trivelin, P. C. O., Ferreira, D. A., Otto, R., Fortes, C., \& Faroni, C. E. (2011). Nitrogênio proveniente da adubação nitrogenada e de resíduos culturais na nutrição da cana-planta. Pesquisa Agropecuária Brasileira, 46(3), 287-293.

Vitti, A. C., Trivelin, P. C. O., Gava, G. J. C., Penatti, C. P., Bologna, I. R., Faroni, C. E., \& Franco, H. C. J. (2007). Produtividade da cana-de-açúcar relacionada ao nitrogênio residual da adubação e do sistema radicular. Pesquisa Agropecuária Brasileira, 42(2), 249-256.

Wiedenfeld, B., \& Enciso, J. (2008). Sugarcane responses to irrigation and nitrogen in semiarid South Texas. Agronomy Journal, 100, 665-671.

\section{Copyrights}

Copyright for this article is retained by the author(s), with first publication rights granted to the journal.

This is an open-access article distributed under the terms and conditions of the Creative Commons Attribution license (http://creativecommons.org/licenses/by/4.0/). 